International Joumal of Biological Sciences
2010; 6(2):192-198

(c) Ivyspring International Publisher. All rights reserved

Research Paper

\title{
Studies on the Developmental Potentiality of Cultured Cell Nuclei of Fish
}

\author{
Hongxi Chen ${ }^{\bowtie}$, Yonglan Yi, Minrong Chen, Xingqi Yang \\ Institute of Hydrobiology, Chinese Academy of Sciences, Wuhan, Hubei Province, P.R. China
}

$\triangle$ Corresponding author: No.7 Donghu South Road, Wuchang District, Wuhan, Hubei Province. Tel: +91-27-68780705; Fax: +91-27-68780705; E-mail: hxchen@ihb.ac.cn

Received: 2010.04.08; Accepted: 2010.04.20; Published: 2010.04.21

\begin{abstract}
By means of the serial nuclear transplantation technique, the authors obtained a nuclear transplant fish from subcultured cell originated from the blastula cells of the crucian carp (Carassius auratus Linnaeus). This nuclear transplant fish survived for three years, but its sexual glands were undifferentiated. The authors have also obtained a sexually mature adult fish from short-term cultured kidney cell nucleus of an adult crucian carp.

Results of the experiment implied that the subcultured cell nuclei of fish blastula cells and the specialized somatic cell nuclei of adult fish still retained their developmental totipotency, and thus, it indicated that there is a possibility of fish somatic cell breeding through the use of nuclear transplantation.
\end{abstract}

Key words: specialized cell nuclei, nuclear transplantation, developmental totipotency

\section{Introduction}

Nuclear transplantation was one of the effective ways in studying cell differentiation, genetic content of somatic cell nuclei and developmental potentiality. For more than twenty years, many authors have utilized nuclear transplantation technique in carrying out experiments in amphibians, which have shown that with the progress of embryo development, especially after late gastrula, the ability of most embryo nuclei in promoting normal development of recipient eggs was dramatically reduced. Some people carried out nuclear transplantation experiments on somatic nuclei (skin, liver, heart, lung, and lymphocytes) of adult frogs cultured in vitro, only to get tadpoles around feeding periods [1-3]. However, Gurdon et al $[4,5]$ once obtained several sexually mature individuals through transplanting cultured epithelial nuclei from feeding tadpoles of Xenopus into enucleated egg of the Xenopus. This showed that in some circumstances, differentiated somatic nuclei can preserve their developmental totipotency in various degrees under the influence of ooplasm. For the above expe- rimental results, some scholars held that while specialized somatic nuclei did experience irreversible changes, somatic nuclei possessed genetic pluripotency. However, some other scholars held that somatic nuclei possessed genetic totipotency without irreversible changes occurred in cell differentiation. Therefore, no consensus was reached on the subject of animal somatic nuclei totipotency. Tong Dizhou, a Chinese scholar in this field, first conducted a series of nuclear transplantation experiments on teleost fishes, studying influences of nuclei and cytoplasm on inheritance character, and have already produced nucleo-cytoplasmic hybrid fish among different fish genera $[6,7]$ and subfamilies [6]. Yet, all these nuclear transplantation experiments on teleost fishes directly utilized undifferentiated blastula cells as donor cells, while experiments using cultured cells including cultured cells of specialized tissues of adult fish as donors have not been studied. Through the methods of cell culture and nuclear transplantation, this experiment explored developmental potentialities of sub- 
cultured cells nuclei produced by culturing fish blastula cells and nuclei of short-term cultured adult fish renal cells after they are transplanted into enucleated eggs. If nuclear transplantation of different types of normally cultured cells can produce adults, various genetic manipulations and processing at cellular level can be carried out, and all kinds of mutation cells can be screened and separated. These will provide important experimental methods and basis for study of fish somatic cell breeding. This paper summarized part of the results of our experiments in this area in recent years.

\section{Materials and Methods}

\section{I. Culture of donor cells}

Several dozens of embryos of crucian carp blastula stage were taken to be processed in Holtfreter's solution containing 'three-anti' (1000L U. penicillin, 1000 micrograms of streptomycin, and 500 micrograms of kanamycin) for half an hour. Then, the embryos were washed twice with low concentration (lower than 1/10) Holtfreter's salt solutions, in which the egg membrane was removed, and the embryo cells were cut from yolk to be drawn into TC-199 culture media for subsequent use.

Primary culture: disinfected blastula cell mass was cut up, and then inoculated in $10 \mathrm{ml}$ streptomycin bottles according to tissue adhesion method, every bottle inoculated with 6 blastula cells of the density of $6.14 \times 10^{3}$ cells per milliliter. The formulation of culture media was as follows, $8 \mathrm{ml}$ of TC-199, $2 \mathrm{ml}$ of calf serum, 100 I.U. penicillin, 100 micrograms of streptomycin and 50 micrograms of kanamycin. Compact monolayer can only be formed after 52-day culture under $27-28{ }^{\circ} \mathrm{C}$.

Subculture: $0.25 \%$ trypsin solution compounded with PBS (-) was used to digest primarily cultured cells. Then, appropriate amount of fresh culture medium was added in after throwing away the trypsin solution, producing suspension with the density of around $1 \times 10^{6}$ cell $/ \mathrm{ml}$, which was inoculated into streptomycin bottles, and subcultured every other 5 days. After 10 passages of subculture, the concentration of calf serum in the culture medium was reduced to $10 \%$, and the subculture inoculation density was 150-200 thousand/ml.

Short-term cultures of renal cells of crucian carps or sexually mature gold fishes: $75 \%$ alcohol tampons were used for surface sterilization. After that, renal tissues of the fishes were taken out through laparotomy, cut up, added into some culture medium, and inoculated into streptomycin bottles according to tissue adhesion method. New cells would grow around tissues several days later. Cell proliferation reached its peak in around a week, and the newly grown cells can act as nuclear transplantation donor cells.

\subsection{Obtaining of recipient eggs}

Sexually mature crucian carps were selected, and as a rule artificial spawning through carp pituitary injection. Thus, a large amount of mature unfertilized eggs were obtained.

\subsection{Nuclear transplantation}

We have worked on the culture of crucian carp blastula cells since April 9th 1979 , and have subcultured more than 50 passages of them till April, 1980. We continued subculture during nuclear transplantation experiments while carrying out short-term culture of renal tissues of sexually mature crucian carps in April, 1980. Thus, ready-made culture cells served as donors in fishes' breeding season in spring. Methods were as follows: take a bottle of subculture cells (53-59 passages) originated from crucian carp blastula or short-term (12-37 days) cultured crucian carp renal cells, throw away culture medium and wash the cells with PBS (-); Then, utilize $0.25 \%$ trypsin solution with PBS (-) as the solvent to digest the cells for several seconds, pour out the solution, and use Holtfreter's solution without $\mathrm{Ca}^{+}$to wash off the remaining trypsin solution; Replace the former solution with Holtfreter's solution in the bottle, rest the bottle for several seconds, and the cells will fall from the walls of bottle, scattering into individual cells, serving as donors of nuclear transplantation. According to fish's nuclear transplantation method by Tong Dizhou et al. [8], individual cultured nucleus was transplanted into unfertilized and enucleated crucian carp egg, and when the recipient egg developed into blastula stage, the second nuclear transplantation was carried out after dissociated solution was used to diffuse the cut off blastula cell mass. This process can also be called serial nuclear transplantation.

\subsection{Chromosome check}

Chromosome check of culture cells basically followed monolayer cell chromosome test method [9]. Chromosome check of caudal fin regeneration tissue was performed according to the method of this laboratory, while that of peripheral blood cells was in line with the regular method.

\section{Results}

\section{I. Nuclear transplantation of subculture cells derived from crucian carp blastula}

In the spring of 1980, we used subcultured cells from crucian carp blastula cells (53-59 generations) as 
donors to be transplanted into enucleated and mature unfertilized crucian carp eggs. 157 of the 189 (83\%) experimental eggs developed into partial blastula or complete blastula, $15(7.9 \%)$ of which further developed into the gastrula stage, indicating that the germinal layer had taken form, the cells had begun to differentiate, and embryo development had been arrested. Only 17 (9.1\%) recipient eggs died from nondivision or irregular division. Take 11 complete blastula from the first nuclear transplantation to act as donors in the second transfers into enucleated eggs of the same species of fish, and 98 (51.8\% of the total transfers) of them developed into the blastula stage, $35(18.5 \%)$ reached the gastrula stage, and $6(3.1 \%)$ embryos reached the stage of heartbeat or embryonic movement. In the end, two fry $(1.1 \%)$ were produced. One abnormally died after seven days, while the other normally lived for as long as three years before being asphyxiated due to poor care in June, 1983 (Table 1; Figure I:1).

\subsection{Nuclear transplantation of short-term cul- tured crucian carp renal cells.}

In the spring of 1982, we selected sexually mature crucian carp renal cells for short-term culture, which were transplanted into enucleated eggs of the same species of fish. Only 32 of the 78 experimental eggs $(41 \%)$ developed into blastula stage, while the other $46(59 \%)$ died from nondivision or irregular division, with no experimental egg developing into early embryo stage. We then took seven complete blastula from the first transfer $19.0 \%$ of the first transfers), and transplanted the blastula cells into enucleated eggs of the same species for the second time. The result was that $55(70.5 \%)$ of the cells developed into the blastula stage, $8(10.2 \%)$ entered the gastrula stage, and one embryo $(1.2 \%)$ during the stage of heartbeat developed into normal fry which became sexually mature adult fish in the end (Table 2; Figure $\mathrm{I}: 2)$.

Table I. Developmental capacity of subcultured cell nuclei derived from crucian carp blastula.

First transfers

\begin{tabular}{|c|c|c|c|c|c|}
\hline Donor cell & Total transfers & $\begin{array}{c}\text { Complete or } \\
\text { partial } \\
\text { blastula }\end{array}$ & Gastrula & Embryos & Fry \\
\hline $\begin{array}{c}\text { Subcultured } \\
\text { cells derived } \\
\text { from blastula } \\
(53-59 \\
\text { passages) (1) }\end{array}$ & 189 & 157 & 15 & 0 & 0 \\
\hline $\begin{array}{c}\text { Proportion of } \\
\text { total transfers } \\
(\%) \text { (4) }\end{array}$ & 83 & 7.9 & 0 & 0 \\
\hline
\end{tabular}

Second transfers

\begin{tabular}{|c|c|c|c|c|c|}
\hline & $\begin{array}{c}\text { Number of } \\
\text { blastula in the } \\
\text { first transfers } \\
8\end{array}$ & $\begin{array}{c}\text { Complete or } \\
\text { partial } \\
\text { blastula }\end{array}$ & Gastrula & Embryos & Fry \\
\cline { 2 - 6 } & 11 & 98 & 35 & 6 & 2 \\
\hline $\begin{array}{c}\text { Proportion of } \\
\text { the first total } \\
\text { transfers (2) }\end{array}$ & 5.8 & 51.8 & 18.5 & 3.1 & 1.1 \\
\hline
\end{tabular}

(1) Subcultured cells from blastula (53-59 passages).

(2) \% of first total transfers.

(8) Blastula number of first transfers.

(4) $\%$ of total transfers. 
Table 2. Developmental capacity of short-term cultured kidney cell nuclei of crucian carp.

\begin{tabular}{|c|c|c|c|c|c|}
\hline \multicolumn{5}{|c|}{ First transfers } \\
\hline Donor cells & $\begin{array}{c}\text { Total } \\
\text { transfers }\end{array}$ & $\begin{array}{c}\text { Complete or } \\
\text { partial } \\
\text { blastula }\end{array}$ & Gastrula & Embryos & Fry \\
\hline $\begin{array}{c}\text { Short-term } \\
\text { cultured kidney } \\
\text { cells (12-37 } \\
\text { days) (1) }\end{array}$ & 78 & 32 & 0 & 0 & 0 \\
\hline $\begin{array}{c}\text { Proportion of } \\
\text { total transfers } \\
(\%) \text { (2) }\end{array}$ & 41 & 0 & 0 & 0 \\
\hline
\end{tabular}

\begin{tabular}{|l|c|c|c|c|c|}
\hline \multicolumn{2}{|c|}{ Second transfers } & Fry \\
\hline & $\begin{array}{c}\text { Blastula } \\
\text { number of } \\
\text { first transfers }\end{array}$ & $\begin{array}{c}\text { Complete or } \\
\text { partial blastula }\end{array}$ & Gastrula & Embryos & 1 \\
\cline { 2 - 6 } & 7 & 55 & 8 & 1 & 1.2 \\
\hline $\begin{array}{l}\text { Proportion of } \\
\text { the first total } \\
\text { transfers (\%) } \\
\text { (3) }\end{array}$ & 9.0 & 70.5 & 10.2 & & \\
\hline
\end{tabular}
(1) Short-term cultured kidney cells (12-37 days).
(2) $\%$ of total transfers.
(3) $\%$ of first total transfers.

Figure I. (I) Nuclear transplant fish of subcultured cell derived from crucian carp blastula. (2) Nuclear transplant fish of short-term cultured kidney cell of crucian carp. (3) Nuclear transplant fish of short-term cultured kidney cell of goldfish. (4) Fry of goldfish. (5) Fry of crucian carp. (6) Heteroploid chromosomes of nuclear transplant fish of subcultured cell derived from crucian carp blastula. (7) Chromosomes of nuclear transplant fish of short-term cultured kidney cell of crucian $\operatorname{carp}(2 n=150 \pm)$. (8) Oocytes of nuclear transplant fish of short-term cultured kidney cell of crucian carp(IV stage,centric or acentric nuclei).

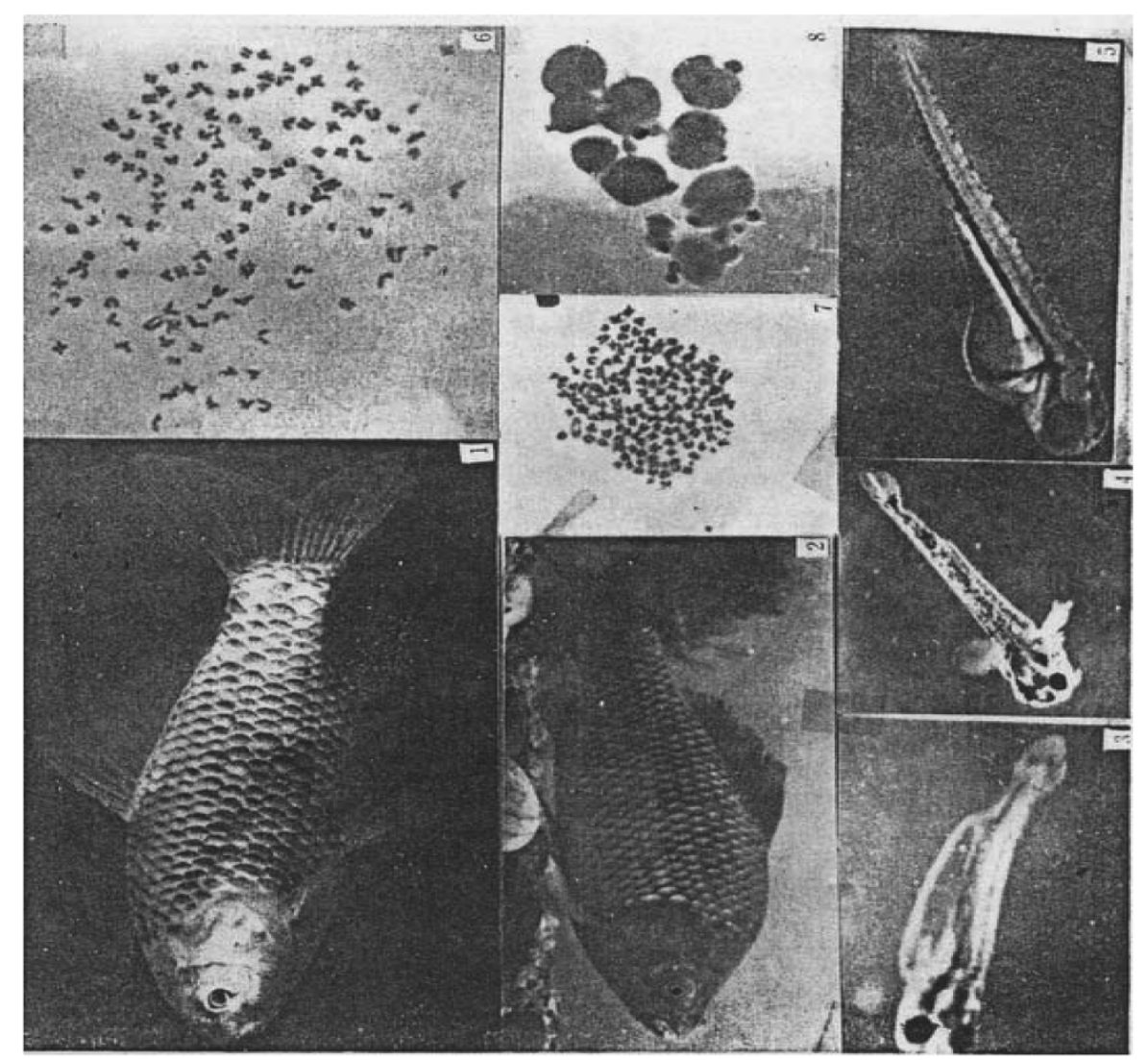




\subsection{Nuclear transplantation of short-term cul- ture of goldfish renal cells}

In the spring of 1984, sexually mature short-term cultured goldfish renal cells were used as donors to be transplanted into enucleated recipient eggs of Carassius auratus cuvieri Temminck et Schlegel or Carassius auratus L. Among the 482 experimental eggs, 298 (61\%) developed into blastula stage, 21 (4.3\%) developed into gastrula stage, and $6(1.2 \%)$ developed into the stage of embryonic movement or heartbeat. We then took 22 blastula from the first nuclear transplantation as donors for the second serial nuclear transplantation to be transplanted into recipient eggs of Carassius auratus cuvieri Temminck et Schlegel or Carassius auratus L. Among these recipient eggs, 208 (43.1\% of the first transfers) developed into the stage of blastula, $26(5.4 \%)$ developed into the stage of gastrula, one $(0.2 \%)$ developed into early-stage embryo, and three $(0.6 \%)$ developed into fry which died abnormally after four days (Table 3; Figure I:3).

Table 3. Developmental capacity of short-term cultured goldfish kidney cell nuclei transferred in to enucleated eggs of either crucian carp or Carassius auratus cuvieri.

First transfers

\begin{tabular}{|c|c|c|c|c|}
\hline Total transfers & $\begin{array}{c}\text { Complete or } \\
\text { partial blastula }\end{array}$ & Gastrula & Embryos & Fry \\
\hline 482 & 298 & 21 & 6 & 0 \\
\hline $\begin{array}{c}\% \text { of total } \\
\text { transfers }\end{array}$ & 61 & 4.3 & 1.2 & 0 \\
\hline
\end{tabular}

Second transfers

\begin{tabular}{|c|c|c|c|c|}
\hline $\begin{array}{c}\text { Blastula numbers } \\
\text { of the first } \\
\text { transfer }\end{array}$ & $\begin{array}{c}\text { Complete or } \\
\text { partial blastula }\end{array}$ & Gastrula & Embryos & Fry \\
\hline 22 & 208 & 26 & 1 & 3 \\
\hline $\begin{array}{c}\text { Proportion of } \\
\text { first total } \\
\text { transfers (\%) (2) }\end{array}$ & 43.1 & 5.4 & 0.2 & 0.6 \\
\hline
\end{tabular}

(1) Blastula number of first transfers.

(2) $\%$ of first total transfers.

\subsection{Chromosome of nuclear transplanted fish}

According to results of chromosome check of caudal fin regenerated tissue cells, nuclear transplanted fish developed from serial nuclear transplantation of subcultured crucian carp blastula cells with aneuploidy chromosome (Figure I: 6). However, adult fish obtained from serial nuclear transplantation of short-term cultured sexually mature crucian carp renal cells have the number of chromosomes of around $2 \mathrm{n}=150$ (Figure I:7).

\subsection{Sexual maturity of nuclear transplanted fish}

In 1980 and 1982, we obtained respectively two nuclear transplanted crucian carp with blastula cells and cultured renal cells. Bred in indoor cement tank, the crucian carp mainly fed on yolk and plankton in the stage of fry, while feeding on tubificidae and artificial food after the stage of young fish. Eight to ten hours of lighting were guaranteed every day. Feeding and growth of the crucian carp were both normal. Wild crucian carps generally reach sexual maturity after a year. Thus, in May, 1981, a year after the crucain carp was obtained, we deduced that the carp was very likely to be male from their external morphology, that is, flat on both sides of the abdominal region. We put a sexually mature female crucian carp into the tank, set an artificial fish nest, and stimulated spawning with carp pituitary in the hope that the female carp could mate with the male one and produce eggs naturally, but we failed. Our effort in activating spawning in the following spring (1982) also ended in failure. In June, 1983, the male crucian carp died from asphyxiation due to poor care. Autopsy showed that this nuclear transplanted fish of subcultured cells originated from crucian carp blastula was a sterile fish as its sexual gland failed to differentiate or grow after being bred for three years.

A serial nuclear transplanted fish obtained from 
short-term cultured crucian renal cells in April, 1982 was determined to be a female fish in May to June in the following year as it had slightly inflated and soft abdomen. We put a sexually mature male crucian carp to mate with it; set artificial fish nest and injected it with carp pituitary extract to activate spawning. We observed estrus phenomenon like chasing between the male and female fish during reaction period of hormone, but the couple did not produce eggs naturally. Yet, after taking out the nuclear transplanted female carp, we pressed the abdominal region slightly with hand and squeezed out more than 10 eggs, which were processed with transparent liquids at once. Microscope assay showed that this patch of egg cell nuclei were in the middle or slightly eccentric, belonging to the IV-stage eggs (Figure I:8). Judging from the fact these egg cells were not sensitive enough towards pituitary gland hormones, they had not reached the maturity level of the end of IV stage yet.

\section{Discussion}

We obtained the two nuclear transplanted fish through transplanting cultured cell nuclei into enucleated eggs of the same species of fish. Thus, a doubt naturally arose are nuclear transplanted fish developed from enucleated eggs originated from donor cell nuclei? Obviously, discretion and care were needed in explaining test results. There are three possibilities: First, recipient cell nuclei were not removed, and female pronucleus was combined with donor nucleus in stimulating experimental eggs to develop into embryos or fry. However, this seldom happens, at least not found in nuclear transplantation of teleost fishes. Even if the combination of egg nuclei and donor nuclei occurs, the nuclear transplanted fishes should be triploids, and usually sterile. Second, the enucleated eggs with no rupture in the donor cell membrane injected with complete cultured cell could not start normal cleavage. If female nuclei may gynogenesis occurs in recipient eggs because of mechanical stimulation of glass needles, the transferred embryos should be haploids, inevitably accompanying haploid syndrome, and will develop into abnormal embryos or die half a month after hatching. Third, donor nuclei do not function except that the female nuclei develop gynogenetically from mechanical stimulations, in other words, the second polar body of recipient eggs will combine with egg pronucleuss. This kind of embryos can develop normally, hatch into fry and survive for a long term to become gynogenetic diploid. Yet, according to our experimental results, resembling that in the amphibians, the first nuclear transplanted embryos seldom develop normally into the stage of gastrula, let alone developing into normal fry. There- fore, cultured somatic cells must pass serial nuclear transplantations in order to obtain 1-2\% individuals. Besides, there is another example of donor nuclei stimulating recipient eggs to develop into fry, that is, caudal fin morphology of the fry obtained through short-term cultured goldfish renal nuclei transplanted into enucleated eggs of Carassius auratus cuvieri Temminck et Schlegel or Carassius auratus L resembles that of goldfish. (Figure I:3,4). From the above, we can understand that the two cultured nuclear transplanted fishes undoubtedly came from the nuclei of the donor cultured cells.

The number of chromosome of crucian carp diploid is 100 , but the number changes dramatically after 60 passages of subculture $(2 n=68-178)$ [10]. Nuclear transplanted fish's chromosomes obtained from this kind of donor cells are usually aneuploids that have dramatic number changes. This is probably because that somatic cell chromosomes of fishes stay in the unstable aneuploidic stage in the culturing process. Therefore, when this kind of nuclei is injected into enucleated eggs, more aneuploidy chromosomes appeared with the cleavage of experimental eggs. Aneuploidy chromosomes may lead to undiferentiation of sexual glands, turning the fish into a sterile one. As for sexually mature renal cells nuclear transplanted crucian carp, the number of chromosomes is always around $2 \mathrm{n}=150$ from chromosome check of cultured caudal cells or leucocytes, but its sexual gland can develop into maturity. This is because the donor nuclei come from renal cells of triploid silver crucian carp instead of triploids combined by diploid donor nuclei $(2 n=100)$ and recipient eggs nuclei $(1 \mathrm{n}=50)$, and this kind of auto-triploid is completely sterile.

Differentiated adult fish somatic nuclei that have been cultured have recovered their division ability, but most donor nuclei were unable to promote recipient eggs to develop normally. Many factors may contribute to this phenomenon, for example, mechanical damage of donor nuclei; donor nuclei not placed in the phase before mitosis in the first proper egg cleavage; incompatibility between donor nuclei and recipient egg cytoplasm; quality of recipient eggs and failure of expression of certain part of gene in the enucleated eggs. The above can all lead to chromosome aberrations, which will cause abortion of nuclear transplanted embryos. Yet, the subcultured blastula cells and short-term cultured crucian carp renal cells both have a small number of nuclei that retain the developmental totipotency, promoting enucleated eggs to become sexually mature individuals.

Above all, we hold that the surviving rate of nuclear transplantation of cultured somatic nuclei can 
possibly be raised with the improvement of technological conditions. As a new way of somatic cell breeding, the possibility for success of genetic process at cellular level and obtaining new individuals through nuclear transplantation still exists.

\section{Acknowledgement}

This is a translation of the following original paper in Chinese: Chen H, Yi Y, Chen M, et al. Studies on the developmental potentiality of cultured cell nuclei of fish. Acta Hydrobiologica Sinica, 1986; 10:1-7. See the editorial: Deng C and Liu H. An Unknown Piece of Early Work of Nuclear Reprogramming in Fish Eggs. Int J Biol Sci 2010; 6:190-191.

We thank Prof. Jiangfeng Cui and Prof. Jiangkang Liu for their support in publishing this paper.

\section{References}

1. Gurdon JB, et al. The developmental capacity of nuclei transplanted from keratinized skin cells of adult frogs. J Embryol Exp Morphol. 1975; 34: 93-112.

2. Lasky RA, Gurdon JB. Genetic content of adult somatic cell tested by nuclear transplantation from cultured cells. Nature. 1970; 228: 1332-1334.

3. Wabl MR. Lymphocytes of the toad Xenopus laevis have the gene set for promoting tadpole development. Science. 1975; 190: 1310-1312.

4. Gurdon JB. The developmental capacity of nuclei taken from intestinal epithelium cells of feeding tadpoles. J Embryol Exp Morphol. 1962; 10: 622-640.

5. Gurdon JB, Uehlimger V. Fertile intestine nuclei. Nature. 1966; 210: 1240-1241.

6. Yan S, et al. Nuclear Transplantation of Teleost Fishes- Hybrid Fishes of Crucian Carp Nuclei and Carp Cytoplasm (CaCy). Sci China Ser C. 1984; 8: 729-782.

7. Yan S, et al. Nuclear Transplantation of Teleost Fishes- Hybrid Fishes of Crucian Carp Nuclei and Carp Cytoplasm. Sci China C Ser. 1980; 4: 376-380.

8. Tong D, et al. Nuclear transplantation of Fishes. Chinese Sci Bul. 1963; 7: 60-61.

9. Shoichi $\mathrm{O}$, et al. Culture of human carcinoma cells. Asakura Bookshop Tokyo. 1975; :61-62.

10. Chen M, et al. Crucian Carp Aneuploid Cellular Line and Their Biological Characters. Journal of Fisheries of China. 1985; 9: 121-130. 